\title{
ДО ПИТАННЯ ПРО ПРИНЦИПИ АДМІНІСТРАТИВНО-ПРАВОВОГО ЗАБЕЗПЕЧЕННЯ ЗАПОБІГАННЯ ТА ПРОТИДІЇ КОРУПЦІї В УКРАЇНІ
}

Приходько А. A.

На думку автора, концепт «принципи адміністративно-правового забезпечення запобігання та протидії корупції в Україні» - це сукупність термінів, які наділені власними характеристиками, однак у сукупному використанні позначають нормативно сформований перелік міжнародних та національних гарантій, засад та антикорупційних стандартів, а також систему звичаєвих правил ефективної діі встановлених законодавством превентивних, репресивних та наслідково-ліквідаційних антикорупційних механізмів. У статmі розкрито чотири групи принципів адміністративно-правового забезпечення запобігання та протидіі корупції.

Ключові слова: адміністративно-правове забезпе чення, антикорупційні механізми, викорінення корупціі, запобігання, корупція, принципи, протидія.

По мнению автора, концепт «принципы администра тивно-правового обеспечения предотвращения и противодействия коррупции в Украине» - это совокупность терминов, которые наделены собственными характеристиками, однако в совокупном использовании обозначают нормативно сформированный перечень международных и национальных гарантий, принципов и антикоррупционных стандартов, а также систему обычных правил эффективного действия установленных законодательством превентивных, репрессивных и следственных ликвидационных антикоррупционных механизмов. В статье описаны четыре группы принципов административно-правового обеспечения предотвращения и противодействия коррупции.

Ключевые слова: административно-правовое обеспечение, антикоррупционные механизмы, искоренение коррупции, коррупция, предотвращение, принципы, противодействие.

According to the author, the concept "principles of administrative and legal support for the prevention and combating corruption in Ukraine" is a combination of terms that are endowed with their own characteristics, but when used together they mean a list of international and national guarantees, principles and anti-corruption standards, as well as a system of ordinary rules effective action of preventive, repressive and investigative-liquidation anti-corruption mechanisms established by law.

The article discloses four groups of principles of administrative and legal support for the prevention and combating of corruption. The author included to them the following components: a) conceptual foundations of Ukraine's orientation towards the development of a civilized country in which a person is not only recognized, but also perceived as the highest social value, and the duty of the state is to provide it with all the necessary benefits; b) advisory, basic principles of the international fight against corruption, the implementation of which provides for the obligation to strictly observe them; c) a system of legal and organizational foundations for the eradication of corruption in Ukraine, standards for the application of preventive

Приходько А. А., 2019 and repressive anti-corruption mechanisms, rules for eliminating the consequences of corruption offenses; $d$ ) a set of guidelines, both common for all and single for a specific representative of the public administration, which determine the content and direction of the administrative activities of anti-corruption bodies, as well as other entities involved in the process of eradicating corruption. The author believes that these components form a system of principles of administrative and legal support for the prevention and combating of corruption.

Key words: administrative and legal support, anti-corruption mechanisms, corruption eradication, corruption, prevention, principles, counteraction.

Постановка проблеми та іï актуальність. Після Революції Гідності боротьба з корупцією стала найбільш пріоритетним напрямом на шляху до євроінтеграції України. Свідченням цього вважається прийняття комплексу антикорупційних законів та створення державно-владних інституцій із попередження корупції [1, с. 102].

Дослідження принципів адміністративно-правового забезпечення запобігання та протидії корупції загалом та діяльності суб'єктів його реалізації зокрема, особливо в умовах вищезазначеного, $\epsilon$ актуальним як для заповнення теоретичних прогалин у галузі адміністративного права, створення підвалин для наступних гносеологічних пошуків у досліджуваній сфері, так і для покращення розуміння та практичної реалізації діяльності таких суб'єктів [2, с. 162].

Аналіз останніх досліджень і публікацій. Окремим питанням про принципи адміністративно-правового забезпечення присвячено праці таких учених, як М. Аракелян, Л. Богачова, О. Іванов, С. Кашкин, В. Колесніченко, Б. Костенко, А. Кухарук, В. Литвиненко, О. Оржель, О. Орловський, О. Прилипчук, А. Пухтецька, $Є$. Ткаченко та інші. Однак до заявленої нами проблематики їхні наукові пошуки звернені не були, а стосувались загальних чи суміжних аспектів.

Метою цієї статті $€$ формування системи принципів адміністративно-правового забезпечення запобігання та протидії корупції в Україні.

Виклад основних положень. За нашим баченням, концепт «принципи адміністративно-правового забезпечення запобігання та протидії корупції в Україні» - це сукупність термінів, які наділені власними характеристиками, однак у сукупному використанні позначають нормативно сформований перелік міжнародних та національних гарантій, засад та антикорупційних стандартів, а також систему звичаєвих правил ефективної дії встановлених законодавством превентивних, репресивних танаслідково-ліквідаційнихантикорупційнихмеханізмів.

Причому ми переконані, що для формулювання системи аналізованих принципів навряд чи доцільно обме- 


\section{Правове забезпечення адміністративної реформи}

жуватися виключно напрацюванням українських учених та національних нормотворців. Позаяк такі принципи фактично закладають підґрунтя та напрями для подальшого розвитку як науки адміністративного права, так і законодавства про запобігання та протидію корупції, до них важливо включити і принципи права Європейського Союзу [3, с. 161].

Зокрема, принципи права ЄС - це основні засади цієї правової системи, які визначають зміст правотворчої, правозастосовної і правоохоронної діяльності Союзу загалом і його держав-членів [4, с. 135; 5, с. 58]. Європейський суд під загальними принципами права ЄC розуміє неписане право $Є C$, а саме загальні принципи міжнародного права та загальні правові принципи, що поділяються всіма державами-членами ЄС. Юридичною підставою включення принципів права до правової системи ЄС виступають установчі договори Союзу [6, с. 48].

На думку деяких правників, загальні принципи союзного права, сформульовані стосовно права Спільноти, становлять третє (поряд з первинними та вторинними) джерело права. Такий підхід не знайшов відображення в договорахабо вторинних джерелахправа, але він помітний у рішеннях Суду. Своєю чергою німецька правова наука відносить загальні принципи права Спільноти до первинного права ЄС і вважає їх доповненням юридичних норм, що містяться в установчих Договорах [7, с. 324].

Наприклад, принцип демократичної рівності припускає забезпечення Союзом у всій своїй діяльності рівності своїх громадян, що користуються однаковою увагою з боку інститутів, органів і установ ЄС. Принцип представницької демократї̈ $є$ важливою основою функціонування Союзу, відповідно до якої держави-члени представлені в інститутах Союзу: у Європейській раді своїми главами держав або урядів, а в Раді - своїми урядами, які самі $\epsilon$ демократично відповідальними перед національними парламентами або перед їхніми громадянами. А громадяни безпосередньо представлені на рівні Союзу в Європейському парламенті. Крім того, кожний громадянин має право брати участь у демократичному житті Союзу, де процес прийняття рішень, наскільки можливо, є відкритим і максимально наближеним до громадян. У формуванні європейської політичної свідомості й вираженні волі громадян Союзу головна роль приділяється політичним партіям європейського рівня. Відповідно до принципу демократії, заснованої на участі громадян, інститути Союзу мають підтримувати відкритий, прозорий і регулярний діалог із цивільним суспільством, адекватними способами забезпечувати можливість громадянам і суспільним об’єднанням громадян доводити до відома про свої думки й привселюдно обмінюватися ними у всіх сферах діяльності Союзу [8, с. 185-186].

Своєю чергою принципи європейського адміністративного права були вперше сформульовані у праці Юргена Шварце “Europaisches Verwaltungsrecht” (з нім. «Європейське адміністративне право») 1988 р.; до них було віднесено: принцип законності; можливість скасування (або відкликання) незаконного адміністративного акта; принцип недискримінації; юридична визначеність; право на захист; принцип пропорційності; принцип поваги до фундаментальних прав людини та громадянина; принцип субсидіарності; принцип належної адміністрації; принцип прозорості; принцип застосування; принцип прямої дії [9, с. 79].
Дефініції (європейські принципи адміністративного права), на думку О. Прилипчук, слід розглядати як сукупність принципів європейського адміністративного права та європейського адміністративного простору, які відображають процеси адміністративної конвергенції та поглиблення інтеграції в Європі. Адміністративні принципи $\epsilon$ не просто ідеями, що спираються на волю управлінців. Вони містяться в організаційних структурах і адміністративних процедурах на всіх рівнях державного управління. Суб'єкти державного (публічного) управління зобов'язані дотримуватися цих правових принципів, що забезпечуються незалежними контрольними органами, системами правосуддя, судочинства та парламентського нагляду [10, с. 48].

Тут важливо уточнити співвідношення принципів європейського адміністративного права із принципами європейського права: принципи європейського права мають загальний характер та застосовуються щодо визначення автономності європейського права, примату над національним правом, безпосередності застосування тощо; а галузь європейського адміністративного права відносить до своїх принципів основоположні вимоги щодо діяльності органів публічної адміністрації та їхніх взаємин із приватними особами [9, с. 79].

У межах власної праці О. Прилипчук [10, с. 49] наводить групову приналежність таких принципів і окремо зазначає, що їх слід відмежовувати від європейських принципів належного урядування. Зокрема, європейськими принципами адміністративного права $\epsilon$ :

1) «юридична визначеність»: принцип правової держави; принцип верховенства права; принцип надійності; принцип передбачуваності; принцип зв'язаності адміністрації законом; принцип недискримінації; принцип пропорційності; принцип доцільності (обґрунтованості); принцип процедурної справедливості; принцип своєчасності; принцип професіоналізму тощо;

2) «відкритість і прозорість»: принцип відкритості на противагу секретності; принцип прозорості на противагу дискретності; принцип винятковості конфіденційного та секретного характеру діяльності органів публічної влади; принцип набрання законної сили тільки після офіційного опублікування; принцип підлеглості публічних адміністрацій зовнішньому контролю; принцип обов'язкового обґрунтування та наведення підстав прийнятого рішення особі, чиї права або законні інтереси зачіпаються у зв'язку з його прийняттям тощо;

3) «відповідальність»: принцип відповідальності органів публічної адміністрації; презумпція вини органу публічної адміністрації у відносинах з громадянином; принцип відшкодування органами публічної влади збитків, заподіяних внаслідок порушення прав і законних інтересів громадян та інших осіб; принцип формалізованих процедур з метою уникнення абстрактної відповідальності; принцип примату інтересів людини і громадянина у відносинах з органами публічної влади тощо;

4) «ефективність і результативність»: принцип ефективної адміністрації; принцип ефективного та результативного виконання європейського законодавства та ін.

Зазначаючи про принципи європейського урядування, слід відзначити, що сама концепція «урядування» не $\epsilon$ новою. Вона така ж стара, як і людська цивілізація. Загалом термін «урядування» означає: процес прийняття рішень та процес, яким це рішення впроваджується (імплементується) або не впроваджується 
(не імплементується). Урядування може бути вживане у декількох контекстах, зокрема, корпоративне урядування, міжнародне урядування, національне урядування, місцеве урядування [11; 12].

Система європейського врядування спирається на розгалужену систему принципів, які, на думку О. Оржель, можна об'єднати у декілька категорій (груп): - засадничі принципи, які також можна охарактеризувати як конституційні: верховенство права, повага до прав та свобод людини, рівне ставлення, відсутність дискримінації;

- принципи належного врядування: субсидіарність, пропорційність, відкритість, ефективність, підзвітність, узгодженість, активна участь громадян;

- принципи, які характеризують європейське врядування як унікальну, специфічну форму взаємодії між різними учасниками процесу прийняття управлінських рішень в $€ С$, вироблення та реалізації європейських політик на наднаціональному, національному, субнаціональному рівнях. Принципами, що визначають особливість, «виокремішність» європейського врядування можна вважати: горизонтальність, розвиненість координації, відносини непідпорядкування та партнерства, що пов'язують його учасників, зростання значення лідерства і комунікації, наявність єдиних стандартів і процедур, що забезпечують ефективність взаємодії в системі європейського врядування;

принципи, на яких ґрунтуються окремі спільні політики чи програми $Є C$, наприклад доповнюваність і комплементарність, характерні для європейської політики згуртування; пристосування європейської комунікативної політики, іiї повідомлень та сигналів до національних, регіональних чи місцевих потреб, забезпечення права громадян $Є C$ на повну та невикривлену інформацію [13, с. 20].

Таким чином, принципи європейського права, європейського адміністративного права та європейського урядування - це концептуальні засади орієнтування України у бік розвитку цивілізаційної країни, у якій людина не тільки визнається, а й сприймається як найвища соціальна цінність, а обов'язком держави $\epsilon$ забезпечення ії всіма необхідними благами.

Окрім загальних європейських засад, визначальне значення мають і спеціалізовані принципи подолання корупції. Як приклад, в ухваленій 15 грудня 1975 року Резолюції Генеральної Асамблеї ООН 3514(XXX) «Заходи проти корупції, що практикуються транснаціональними й іншими корпораціями, їх посередниками та іншими причетними до цього сторонами» [14] закріплені такі антикорупційні принципи: 1) засудження всіх проявів корупції; 2) системного вжиття заходів запобігання транснаціональним проявам корупції; 3) міжнародної співпраці; 4) ведення статистичних та моніторингових інформаційних матеріалів про стан корупції в окремо взятій країні.

У Декларації ООН про боротьбу з корупцією і хабарництвом у міжнародних комерційних операціях від 16 грудня 1996 р. закріплені такі як: принцип ефективних та конкретних заходів боротьби з усіма формами корупції; принцип криміналізації за дачу хабарів; принцип єдиних стандартів і методів обліку; принцип визнання незаконного збагачення державних посадових осіб або обраних представників злочином; принцип міжнародного співробітництва [15].
Відповідною Резолюцією № R(97) 24 визначено 20 основних засад, як така діяльність має реалізовуватися на національному рівні, зокрема необхідно: 1) проводити ефективні заходи для запобігання корупції та в зв'язку з цим піднімати суспільне розуміння і просування етичної поведінки; 2) гарантувати визнання національної та міжнародної корупції кримінально караним діянням; 3) гарантувати, що ті, хто відповідає за запобігання, розслідування, судове переслідування і судове рішення по випадках корупції $\epsilon$ незалежними й автономними; 4) забезпечувати відповідні заходи для конфіскації і позбавлення доходів у результаті випадків корупції; 5) забезпечувати відповідні заходи, щоб запобігти тиску на юристів, які займаються викриванням корупції [16].

А основними принципами Стамбульського плану дій $\epsilon$ розвиток ефективної і прозорої системи державної служби, посилення боротьби з хабарництвом та забезпечення чесності в бізнесі, підтримка активної участі громадськості у реформах $[17$, с. 14$]$.

Окремо зазначимо, що згідно з Модельним законом «Основи законодавства про антикорупційну політику» від 15 листопада 2003 року, принципами антикорупційної політики $\epsilon:$ 1) партнерство суб'єктів формування та реалізації заходів антикорупційної політики; 2) пріоритет заходів попередження корупції і моральних начал боротьби з корупцією; 3) неприпустимість встановлення антикорупційних стандартів нижче рівня, визначеного законами держави; 4) неприпустимість покладання на одного і того ж суб'єкта антикорупційної політики відповідальності за розробку, реалізацію і контроль над реалізацією заходів антикорупційної політики; 5) підтримання оптимальної чисельності осіб, що заміщають державні посади, і осіб, які перебувають на державній і муніципальній службі; 6) цільове бюджетне фінансування заходів антикорупційної політики; 7) визнання підвищеної суспільної небезпеки корупційних правопорушень осіб, що заміщають посади, передбачені конституцією й іншими законами держави; 8) неприпустимість обмеження доступу до інформації про факти корупції, корупціогенні фактори та заходи реалізації антикорупційної політики [18].

Ці та інші принципи поступово імплементуються у вітчизняне законодавство. Як приклад, у Законі «Про засади запобігання і протидії корупції», що діяв у 2013 році, було задекларовано перелік принципів антикорупційної діяльності, які $\epsilon$ міжнародно визнаними стандартами. Перелік не $\epsilon$ вичерпним, але всі принципи тією чи іншою мірою знайшли втілення у конкретних нормах. На думку Б. Костенко, А. Кухарук та Т. Саченко, редакційна недосконалість викладення не зменшує цінності окреслення умов протидії корупції $[17$, с. 21].

Чинний Закон України від 14.10.2014 року № 1700-VII «Про запобігання корупції» [19] не передбачає принципів запобігання і протидії корупції. Однак аналіз антикорупційного законодавства до принципів дає підстави віднести такі як: принцип верховенства права; принцип законності; принцип комплексного здійснення правових, політичних, соціально-економічних, інформаційних та інших заходів; принцип пріоритетності запобіжних заходів; принцип невідворотності відповідальності за вчинення корупційних та пов'язаних з корупцією правопорушень; принцип відкритості та прозорості діяль- 
ності органів державної влади та органів місцевого самоврядування; принцип участі громадськості у заходах щодо запобігання і протидії корупції [20].

Остатню групу аналізованих принципів становлять принципи адміністративної діяльності публічної адміністрації у сфері запобігання та протидії корупції. Наприклад, до системи принципів діяльності антикорупційних органів входять: 1) загальноправові, які визначають базові засади діяльності центральних органів виконавчої влади зі спеціальним статусом і деталізують правовий статус антикорупційного суб'єкта; 2) спеціальні, що безпосередньо спрямовані на забезпечення діяльності органу, які розподіляються на: а) моральні та професійно-етичні; б) керівні (професійні) принципи [1, с. 122].

Висновки. Усе вищевикладене дає можливість сформулювати висновок, згідно з яким систему принципів адміністративно-правового забезпечення запобігання та протидії корупції становлять:

1) принципи європейського права, європейського адміністративного права та європейського урядування як концептуальні засади орієнтування України у бік розвитку цивілізаційної країни, у якій людина не тільки визнається, а й сприймається як найвища соціальна цінність, а обов'язком держави $є$ забезпечення іï всіма необхідними благами;

2) міжнародні антикорупційні стандарти як рекомендаційні, базові основи боротьби з корупцією, імплементація яких передбачає обов'язок їх неухильного дотримання;

3) національні антикорупційні стандарти як система правових та організаційних засад викорінення корупції в Україні, стандартів застосування превентивних та репресивних антикорупційних механізмів, правил щодо усунення наслідків корупційних правопорушень;

4) принципи діяльності публічної адміністрації у сфері запобігання та протидії корупції як сукупність керівних настанов як спільних для всіх, так і одиночних для конкретного іï представника, що визначають зміст та спрямованість адміністративної діяльності антикорупційних органів, а також інших суб'єктів, залучених до процесу викорінення корупції.

\section{Література}

1. Іванов О.В. Адміністративно-правовий статус Національного агентства 3 питань запобігання корупції : дис. ... канд. юрид. наук : 12.00.07. Науково-дослідний інститут публічного права. Київ, 2019. 304 с.

2. Литвиненко В.І. Мета та принципи діяльності суб'єктів протидії корупції. Форум права. 2015. № 4. С. 162-168.

3. Орловський О.С. Принципи сучасного українського муніципалізму: постановка проблеми. Актуальні пробле ми держави і права. 2012. Вип. 64. С. 160-165.

4. Кашкин С.Ю. Право Европейского Союза : учебник для вузов. Москва : Юрайт : Высш. образование, 2010. 1119 с

5. Аракелян М.Р. Право Європейського Союзу : підручник для студентів вищих навчальних закладів. Одеса : Фенікс, 2012. 390 с.
6. Богачова Л.Л. Принципи європейського і національного права (порівняльно-правовий аналіз критеріїв класифікаціі). Державне будівництво та місцеве самоврядування. 2013. Вип. 26. С. 47-60.

7. Ткаченко $€$.В. Загальні принципи права в правовій системі Європейського Союзу. Університетські наукові записки. 2009. № 1. С. 323-330.

8. Колесніченко В.В. Принципи права Європейського Союзу у світлі Лісабонського договору. Актуальні проблеми політики : зб. наук. пр. / ред. кол.: С.В. Ківалов (керівник авт. кол.), Л.І. Кормич (ред.), М.А. Польовий (відп. секр.) та ін. ОНЮА, Південноукр. центр ґендер. проблем. Одеса, 2009. Вип. 36. С. 181-187.

9. Пухтецька А.А. Поняття та принципи європейського адміністративного права. Наукові записки НаУКМА. Юридичні науки. 2012. Т. 129. С. 78-81.

10. Прилипчук О. Європейський адміністративний простір: принципи та засади. Державне управління та місце ве самоврядування. 2016. Вип. 2. С. 46-50.

11. Що $\epsilon$ належне урядування? Центр політико-правових реформ. URL: https://pravo.org.ua/files/ administr/reforma/What\%20is\%20good\%20governance\%20\% 28ukr\%29.doc.

12. Official documents issued by ESCAP. UNESCAP. URL: http://www.unescap.org/ huset/gg/governance.htm.

13. Оржель О. Принципи європейського врядування. Вісник Національної академії державного управління при Президентові України. 2009. Вип. 4. С. 10-20.

14. Меры против коррупции, практикуемой транснациональными и другими корпорациями, их посредниками и другими причастными к этому сторонами: Резолюция Генеральной Ассамблеи ООН от 15 декабря 1975 року 3514 (XXX). UNDOCS. URL: https://undocs.org/ ru/A/RES/3514\%28XXX\%29.

15. Декларація ООН про боротьбу з корупцією і хабарництвом у міжнародних комерційних операціях від 16 грудня 1996 р.: Міжнародні правові акти та законодавство окремих країн про корупцію. Київ : Школяр, 1999. С. 83-87.

16. Резолюція Комітету міністрів Ради Європи «Про двадцять принципів боротьби з корупцією»: Міжнародний документ від 06.11.1997 № R(97)24. / Верховна Рада України. URL: https://zakon.rada.gov.ua/laws/show/ 994_845.

17. Костенко Б.О., Кухарук А.В. Імплементація європейських стандартів запобігання та боротьби з корупцією в національне законодавство : навчально-методичні матеріали / уклад. Т.А. Саченко. Київ : НАДУ, 2013. 60 с.

18. Модельний закон «Основи законодавства про антикорупційну політику» : Міжнародний документ від 15.11.2003. / Верховна Рада України. URL: https://zakon. rada.gov.ua/laws/show/997_944/ed20031115/find?text=\%CF \%F0\%E5\%E4\%F3\%EF\%F0\%E5\%E6\%E4\%E5\%ED\%E8\%E5+\%EA\%EE\%F0 \%F0\%F3\%EF\%F6\%E8\%E8.

19. Закон України від 14.10.2014 року № 1700-VII «Про запобігання корупції». Голос України. 2014. № 206.

20. Іванцов В.О. Принципи запобігання та протидії корупції: аналіз антикорупційного законодавства. Правові, економічні та соціальні аспекти протидії корупції : матеріали наук.- практ. семінару (Миколаїв, 20-21 травня 2016 р.). НУК, 2016.

Приходько А. А., кандидат юридичних наук, адвокат 